\section{ECONOMICS}

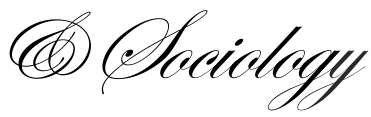

\title{
CUSTOMER SATISFACTION AND ITS MEASUREMENT IN FITNESS CLUBS OF WARSAW
}

\author{
Sylwia Gocłowska, \\ Józef Pitsudski University of \\ Physical Education, \\ Warsaw, Poland, \\ E-mail: \\ sylwia.goclowska@awf.edu.pl \\ Monika Piątkowska, \\ Józef Pitsudski University of \\ Physical Education, \\ Warsaw, Poland, \\ E-mail: \\ monika.piatkowska@awf.edu.pl \\ Michał Lenartowicz, \\ Józef Pitsudski University of \\ Physical Education, \\ Warsaw, Poland, \\ E-mail: \\ michal.lenartonic_@anw.edu.pl
}

Received: October, 2018

1st Revision: March, 2019

Accepted: June, 2019

DOI: $10.14254 / 2071-$

789X.2019/12-2/12

\begin{abstract}
Consumer satisfaction is an important issue in marketing research and consumer surveys. In the literature on the subject, there is a consensus among researchers regarding the requirement to design tools measuring consumer satisfaction for various industry sectors. Because of that, the authors of the article decided to design their own consumer satisfaction survey adapted for one of the biggest fitness club chain in Warsaw. An innovation of the designed tool is a comprehensive reference to the overall line of business of the fitness organization in accordance with the $7 \mathrm{P}$ theory for services, relating to marketing instruments used by organizations to influence the customer. The aim of this work is to present the methodology of designing and using the CSI (Customer Satisfaction Index) for companies providing fitness services. Designed approach can be universal for all fitness companies providing fitness services and it covers all 7 instruments of marketing mix. The methodology of measuring customer satisfaction seems to be adapted to the nature of customers of the fitness sector as well as small and medium enterprises dominating in this field. Measuring customer satisfaction makes it possible to take decisions and contributes to the quality of the services offered.
\end{abstract}

JEL Classification: M31, I11, $\mathrm{O} 10$

Keywords: satisfaction, measurement, fitness clubs, Poland, CSI, marketing.

\section{Introduction}

Consumption is one of the key categories of analysis in contemporary social sciences. Understood as acquisition and use of products and services, in terms of its definition, it belongs to the sphere of economy but for years focus has been shifted to its various noneconomic dimensions and consequences (Aldridge, 2006; Baudrillard, 2006; Bauman, 2000; Bourdieu, 2005; Giddens, 2002; Ritzer, 2009). The aspiration to satisfy customers' needs has led to the formation of a new "enchanted" means of consumption (Ritzer, 2009) and the need to efficiently manage sales and customer service to the continuously progressing rationalisation thereof. Leisure time and sports are, of course, very important areas of 
consumption. Customer satisfaction with services is extremely important to companies operating in this sector. In wealthy societies, "consumption has even less to do with acquiring goods and services but ever more with entertainment" (Ritzer, 2009, p. 313) and offering pleasure in staged conditions of new means of consumption.

Consumer satisfaction with the products and services, although difficult for accurate assessment, is an important issue in marketing and consumer research. Customer satisfaction is particularly important to the service sector where customer retention is the only way for an organization to achieve success (Kim \& Lough, 2007) - "customer satisfaction is essential for a company's success" (Shin \& Elliott, 2001, p. 4). To acquire and maintain customers, companies take various measures focused on acquiring information about consumer preferences, needs, hobbies, lifestyle, and consumption style. Lee et al. (2011) believe that the basic activities of managers in today's organisations should comprise a systematic analysis of the quality and level of satisfaction with services from the consumers' point of view and an adaptation of the offer to the identified expectations.

The concept of customer satisfaction has been defined by many authors in literature to date and is differently conceptualized depending on a product and business sector. Researchers mutually agree that consumer satisfaction studies strongly depend on the specific research problem, the sector, as well as the specific product or service (Śmiatacz, 2012). In general, it is regarded as a measurement of the effectiveness of various undertakings carried out by organizations, which are associated with a product or a general review of various attributes that make up a product, or a given service function (Johnston, 1995; Swan \& Combs, 1976). With the appearance of consumer satisfaction, we come up against the following: "if performance is higher than expected, dissatisfaction results if it is lower" (Bartikowski \& Llosa, 2004, p. 69).

Together with the development of the theory of relationship marketing and the shift of focus to the significance of measurement and assessment of customer satisfaction, a number of methods aimed at measuring customer satisfaction have been developed (Milner \& Furnham, 2017; Seth et al., 2005). Customer satisfaction research is usually conducted using techniques and tools that are typical of classic quantitative and qualitative marketing research. The majority of methods available in literature can be attributed to one of two categories of measuring customer satisfaction: direct and indirect (Woodruff \& Gardial, 1996, pp. 223224). Direct methods are those based on customer's opinion, whereas in indirect methods, the measurement of satisfaction is not directly associated with opinions (Bartikowski \& Llosa, 2004). In case of the latter, companies draw conclusions about their customers' level of satisfaction, focusing indirectly on facts and not on the opinions of customers, by analysing inferential indicators (Mayntz et al., 1985, p. 51), such as quantity of products or services sold, sales trends, the number of repeated purchases or services, or the market share. Quantitative and qualitative reports from the departments having direct contact with customers can also be an element of a whole array of indicators used to determine customer satisfaction. Companies assume that if the consumer is satisfied with the service, they will then make a purchase again, perhaps recommend the company to other customers, thus, leading the company to gain a higher market share (Rekha et al., 2016). Direct methods of measuring customer satisfaction also include examining complaints and suggestions, scrutinizing the CSI (Customer Satisfaction Index), the SERVQUAL method, and the CIT (Critical Incident Technique) (Nieżurawski et al., 2010). Indirect methods and related conclusions concerning relationships between the data being analysed and the level of customer satisfaction are used but are considered to be less credible than direct research (Haffer, 2000). Such a method of drawing conclusions may be unreliable due to the potential interference of numerous variables in the relationship between the studied indicators and the satisfaction variable, and due to the fact that the level of customer satisfaction may be affected 
by many other factors associated with company's operations (e.g., company image, seasonal trends, meteorological factors etc.). Some of authors believe that satisfaction is inseparably associated with the parameters of the provided service and should be analysed through the prism of this quality (Alexandris \& Palialia, 1999; Tsitskari et al., 2006). To ensure greater credibility, only direct methods of measuring customer satisfaction are presented in detail below.

The literature on the subject also discusses the breakdown of methods measuring customer satisfaction into two: a traditional approach with an aggregate (single-item), and a comprehensive approach involving a modern attribute (multi-item) level of measurement (Elliott \& Shin, 2002). Normally, general customer satisfaction with a product or service is measured by asking a simple "yes" or "no" question about the level of overall satisfaction (e.g., on a scale ranging from "completely dissatisfied" to "completely satisfied", or "poor" to "excellent"). However, this approach does not take into account the numerous quality attributes of products or services. It does not measure customers' various degrees of satisfaction with each of these attributes (Shin \& Elliott, 2001). An alternative, more modern approach is the Multi-Attributes Rating, which combines all product or service attributes, customer's various levels of satisfaction with a given attribute, and the relative importance of each of the attributes. These attributes are obtained and evaluated from every customer participating in the survey. The level of overall satisfaction of every customer is measured by a weighted average of the difference between the customer's expectation of performance (importance rating) and the actual experience (performance rating) relating to each attribute, and the relative importance of each attribute perceived by the overall customer group. Each customer can be labelled as either "very satisfied" or "very dissatisfied". Other scales preferred by managers can also be used. These may include a computed satisfaction score rather than a customer's own self-reported score (Shin \& Elliott, 2001).

Due to the complexity of the aspects associated with satisfaction, the existence of many customer satisfaction models, the lack of agreement as regards the elements that have a direct impact on satisfaction, the development of universal tools and studies and the management of consumer satisfaction are becoming very complex (Maison \& Bruin, 1998). Therefore, this calls for the design of tools that are dedicated to specific sectors or even brands, which was emphasized by Alexandris and Palialia (1999) in one of the first studies of satisfaction of customers of commercial fitness centres in Greece. Due to the identified specific nature of the fitness club sector, the authors did not use any of the available research tools but developed their own unique instrument.

Inspired by this the authors decided to design their own consumer satisfaction survey that would be tailored to the fitness club sector in terms of the marketing instruments used by organisations for exerting an influence on the customer. Studies on the organisation's satisfaction using the CSI, with reference to the 4P marketing instruments (the product, price, promotion and place are the 4Ps of the traditional marketing mix as developed by McCarthy in 1960), can be found in literature (Baidya \& Basu, 2009). However, it should be pointed out that these studies are not tailored to the service or recreational sector. The services marketing mix theory consists of 7 instruments used by organizations to influence customers (Anitsal et al., 2012). It was Shostack (1977) who sparked the need for marketing mix elements to evolve. The author recommended that the marketing mix be expanded and include both the participants and the physical evidence of the services rendered. Then, Booms and Bitner (1981) extended the 4Ps mix by including three additional instruments: participants, physical evidence, and process. They called it 7Ps of the services marketing mix. No results were found in the available literature on the subject of fitness centre customer satisfaction using all 7Ps. Thus, the authors decided to design a unique research tool based on the theory of the 7Ps of the marketing mix and to use the modern and multi-dimensional CSI to analyse the data. 


\section{Literature review}

The fitness services sector in Poland is currently undergoing rapid development. Annual sector analyses indicate an increase in revenues from this sector and a growing sports and leisure activity participation at fitness clubs (Table 1). Based on these data, which came from an analysis of the measure of the volume and development potential of the fitness market in Poland (Rutgers et al., 2017), Poland is regarded as the most rapidly developing fitness services market when compared to all other European Union states (Krupa, 2017). In this scope, Poland ranks among the top ten European players in the whole fitness market (Rutgers et al., 2016; 2017). The Polish fitness club market is fragmented with numerous small organisations operating within the sector. Most of them are private enterprises. Organizations providing fitness services in Poland are concentrated in large urban agglomerations (Meissner, 2013). Berbeka et al. (2004, pp. 5-8) note that modern consumers are increasingly demanding and aware of the opportunities available to them by a wide and extensive supply offer. Their tastes and preferences change quickly, and the pace of change is related to the number of new products appearing on the market. All these factors influence the need to closely scrutinize consumer satisfaction in order to identify, understand, anticipate, and shape it.

Table 1. Measures of the market volume and the development rate of the fitness market in Poland in 2013-2016

\begin{tabular}{lccccc}
\hline \multicolumn{1}{c}{ Indicators } & \multicolumn{5}{c}{ Year } \\
\cline { 2 - 7 } & 2017 & 2016 & 2015 & 2014 & 2013 \\
\hline Number of clubs & 2600 & 2560 & 2520 & 2500 & 2400 \\
\hline Total membership (m) & 2,91 & 2,84 & 2,77 & 2,73 & 2,48 \\
\hline Revenue of fitness clubs in Poland (m EUR) & 872 & 842 & 871 & 860 & 834 \\
\hline Penetration rate (\%) & 7,7 & 7,4 & 7,3 & 7,1 & 6,4 \\
\hline Average membership fee (EUR) & 27,9 & 27,7 & 29,3 & 29,4 & 30,6 \\
\hline
\end{tabular}

Source: Rutgers et al. (2015, 4-5; 2016, 122-123; 2017, 9-11, 2018, 150-177) and the Public Relations Office (2015).

\section{Purpose of research}

The aim of this work is to present the methodology for the design and use of the CSI by companies providing fitness services. The study also contributes to the formulation of the satisfaction concept and policy by considering the actual factors predicting customer satisfaction adapted to the fitness sector. An innovative element of this approach is the comprehensive reference to the overall business activity of a fitness organisation in accordance with the 7Ps service marketing mix theory.

\section{Methodological approach}

\subsection{Procedures}

In order to achieve the assumed objectives, we examined participants of sports and leisure activities from two clubs located in the largest city in Poland that belong to one of the largest nationwide networks of clubs operating in the fitness services industry. The selection of the sample was intentional due to the strictly defined research goal and the expected results regarding the largest fitness chain in the country with branches in the largest Polish city, 
facing fierce competition from other enterprises. The studies used a purposeful selection of critical cases, which involved the selection of objects that best represent the studied problem (Flick, 2012, p. 59), which, in this case, meant the largest and most dynamically operating organisations with numerous clubs throughout the city and an extensive offer of services. This nationwide network of fitness centres can function due to its enormous number and diverse range of sports and leisure activities. Participants who choose this chain show their satisfaction with the services provided, thus enabling the organization to develop further. At the study design phase, the criteria set by the authors were met by the Zdrofit company, which has 22 fitness clubs in Warsaw and 20 clubs in other Polish cities. This Polish company has operated since 2005 with year-on-year its increasing market share. At the end of the 2018, Zdrofit took over part of the Calypso clubs, previously the biggest fitness chain in Poland. Now, the Zdrofit company is the largest chain of fitness clubs in Poland with 61 clubs in total, 31 of which are in Warsaw.

The survey was conducted in late May and early June of 2016. A trained interviewer distributed paper questionnaires in two fitness clubs belonging to one brand, Zdrofit, in Warsaw and collected them together with a signed written consent to participate in the study.

\subsection{Survey design}

We conducted a quantitative survey and used an original questionnaire examining the seven marketing elements of fitness club operations. The tool was designed to allow consumers to evaluate their own satisfaction with the sports and leisure activities available, and the significance of the seven areas of the club's operations presented in Table 2.

Table 2. Encoding the 7P instruments in the designed tool

\begin{tabular}{ll}
\hline \multicolumn{1}{c}{ 7P's instruments } & \multicolumn{1}{c}{ Area in the designed tool } \\
\hline Product & Exercise classes offered and other services of the club \\
\hline Price & Price of exercise classes and other services \\
\hline Promotion & Promotional activities of the club \\
\hline Place (distribution) & Club location \\
\hline Physical evidences & Appearance and equipment of the club \\
\hline People & Fitness club staff \\
\hline Processes & Other aspects of the club operation \\
\hline
\end{tabular}

Source: own compilation.

The study used an original survey questionnaire covering the marketing elements of fitness club operations based on a tool prepared by Alexandris and Palialia (1999). We adapted and extended their tool with a greater number of factors presented in literature, allowing for a better assessment of the level of respondent satisfaction. We added new parameters according to the theory of service marketing and its 7 instruments based on literature research. Each area was measured on a 5-point Likert scale, in two dimensions: service satisfaction (from dissatisfied to very satisfied), and the significance of the tested parameters (from unimportant to very important).

\subsection{Participants}

This paper presents the results of a survey conducted among the target respondent population- members of two selected fitness clubs belonging to the Zdrofit company in Warsaw $(\mathrm{N}=76)$. Respondents were asked to take part in the survey by trained interviewers 
while leaving the club. Those who agreed to participate in the study completed the survey themselves, in writing, directly in the club. The sample characteristics are presented in Table 3.

Table 3. Characteristics of the studied population

\begin{tabular}{lcc}
\hline & Factors & Entire population examined $(N=76)$ \\
\hline Gender & $\mathrm{N}$ & $\%$ \\
\hline Women & 45 & 59.2 \\
\hline Men & 31 & 40.8 \\
\hline Age & 1 & 1.3 \\
\hline$<19$ & 16 & 21.2 \\
\hline $20-24$ & 18 & 23.7 \\
\hline $25-29$ & 17 & 22.4 \\
\hline $30-39$ & 9 & 11.8 \\
\hline $40-49$ & 10 & 13.2 \\
\hline $50-59$ & 5 & 6.6 \\
\hline$\geq 60$ & & 6.8 \\
\hline Education & 5 & 21.2 \\
\hline elementary & 16 & 72.0 \\
\hline secondary & 55 & \\
\hline higher & & 21.1 \\
\hline Marital status & 32 & 1.3 \\
\hline Married & 1 & 3.9 \\
\hline Widow/er & 3 & 52.6 \\
\hline Divorced & 40 & 16.0 \\
\hline Single & & 9.3 \\
\hline Household net monthly income per capita & 12 & \\
\hline$<$ PLN 800 & 44 & 58.7 \\
\hline PLN 801-1500 & 12 & \\
\hline PLN 1501-2500 & 7 & \\
\hline$\geq$ PLN 2501 & & \\
\hline
\end{tabular}

Source: own compilation.

\subsection{Data analysis}

The data analysis was based on the calculation of the Customer Satisfaction Index (CSI), which measures the level of profitable satisfaction of a given customer base and the influence of this satisfaction on the selected measure of economic performance. It is one of the basic and most widely used marketing indicators used to assess the effectiveness of marketing activities in the dimension of consumer satisfaction. The Customer Satisfaction Index (CSI) determines the level of consumer satisfaction from defined areas of the organisation's activity. The CSI provides the grounds for determining whether the market is becoming more or less satisfied with the quality of products or services offered by an individual company or industry (Al-Nasser et al., 2011). The CSI also shows which determinants of declared consumer satisfaction are the most important to consumers (Nieżurawski et al., 2010), which is possible due to the weights assigned to particular evaluation parameters. The concept of the CSI has been gradually gaining world recognition from the 1990s. The first variant of the CSI was the American Customer Satisfaction Index (ACSI), which is considered to be the prototype of other indicators used in marketing. The ACSI was created in 1996 by Fornell et al. (1996) to evaluate the satisfaction levels of firms, industries, and economic sectors in the US. The idea was to take more accurate measures of performance of a modern economy (Yu et al., 2007). Since then, many CSIs have been 
developed for various fields or countries (e.g., the European Customer Satisfaction Index ECSI (Hsu et al., 2006).

Statistical analysis was performed with IBM SPSS Statistics (Version 22). The statistical inference comprised descriptive statistics, where a brief outline of the variables tested was made using the arithmetic mean (x), the median (me) and the standard deviation (SD) to provide a customer satisfaction matrix of the studied fitness club.

\section{Results}

The first thing that was studied was the average scores awarded in the areas studied on the satisfaction and significance scale (Table 4). Customers' scores were converted to points where 1 point meant dissatisfied, and 5 points - very satisfied in case of the satisfaction scale, and 1 point meant unimportant and 5 points - very important in the case of the significance scale. All the "not applicable" and "no opinion" responses were treated as missing values. The data analysis revealed 43 instances of no responses, 277 indications of "not applicable", and 623 "no opinion" replies.

Table 4. Average scores awarded in the areas studied on the satisfaction and significance scale

\begin{tabular}{lcccccc}
\hline Area studied & \multicolumn{2}{c}{ Satisfaction scale } & \multicolumn{3}{c}{ Significance scale } \\
& Mean & Me & SD & Mean & Me & SD \\
\hline Fitness club's staff & 3.92 & 3.78 & 0.74 & 4.32 & 4.44 & 0.56 \\
\hline Exercise classes and other services offered & 3.58 & 3.6 & 0.59 & 3.77 & 4.0 & 0.78 \\
\hline Price of exercise classes and other services & 3.31 & 3.25 & 0.7 & 4.1 & 4.0 & 0.72 \\
\hline Promotional activity of the club & 3.38 & 3.44 & 0.57 & 3.66 & 4.0 & 0.64 \\
\hline Appearance and equipment of the club & 3.53 & 3.36 & 0.71 & 4.28 & 4.36 & 0.57 \\
\hline Club location & 3.42 & 3.2 & 0.8 & 4.17 & 4.0 & 0.59 \\
\hline Other aspects of the fitness club's operation & 3.81 & 4.0 & 0.88 & 4.12 & 4.17 & 0.74 \\
\hline
\end{tabular}

Source: own compilation.

The mean from each area was calculated on the basis of more detailed parameters. For instance, on the satisfaction and significance scale in the area concerning the fitness club's staff, the consumers rated the attitude of the club's staff towards customers, the attitude of instructors and coaches towards customers, their experience, contact with the fitness club goers, their physical dexterity and physical appearance, involvement during classes, and the way classes were conducted. An analysis of the individual parameters was the subject of the authors' other work (Gocłowska \& Piątkowska, 2017).

Based on the calculated statistics presented in Table 4, a matrix of customer satisfaction accounting for the importance of indicators and the degree of customer satisfaction (Graph 1) was developed. Considering the average values of satisfaction and importance, the diagram can be divided into four main quarters corresponding with the four strategic fields of SWOT analysis: strengths, weaknesses, opportunities, and threats. However, it must be noted that median values obtained from the results of the questionnaires were used and not the midpoint of the range in the analysis of significance and satisfaction, as a measure of the intersection of the axes. This is because the global median values for the axes reveal the trend of the attributes (Lynch et al., 1996; Martilla \& James, 1977). For our work, the cut-off lines calculated in all 7 areas are $M e=3.5$ for the satisfaction scale, and $\mathrm{Me}=4.1$ for the significance scale.

Quarter 1 is the area of the highest importance out of the areas surveyed by the respondents and, at the same time, the area of their lowest satisfaction. According to the 
SWOT theory, this zone shows the threats of the organisation. Only the area associated with the club's location was fully placed within quarter 1 (e.g., the club's signs, the number of parking bays, the public transport options to get to the club). This is a priority area for improvements. The prices in fitness clubs are in the middle of Q1 and Q3. Quarter 2 contains areas that have reached the highest average satisfaction and the highest average validity. It is a zone of achieved strengths. Areas placed here should be maintained at the same level. Out of all the areas being analysed, three were found in Q2: fitness club's staff, appearance and equipment of the club, and other aspects of the fitness club's operations, containing evaluation parameters such as access to information about classes, efficiency and speed of customer services, or the club's opening hours. Quarter 3 is an area of the lowest priority, which covers the prices of the exercise classes and other services and promotional activities of the club. Zone Q3 contains the lowest rated areas based on average satisfaction and validity. According to the SWOT theory, this is a zone of the organisation's weaknesses. The last area $\mathrm{Q} 4$, is the field of the highest respondent satisfaction and, at the same time, of the lowest importance of the studied areas, also referred to as an opportunity zone for the organisation. Quarter 4 shows the area of second priority, which includes exercise classes and other services offered.

The aforementioned areas should constitute a starting point for the managers of fitness clubs in defining the organisations' future strategic goals. The matrix prepared in this manner can also be used in each area, placing the parameter scores on the diagram. By doing so we are able to define the tactical goals of the organisation being studied.

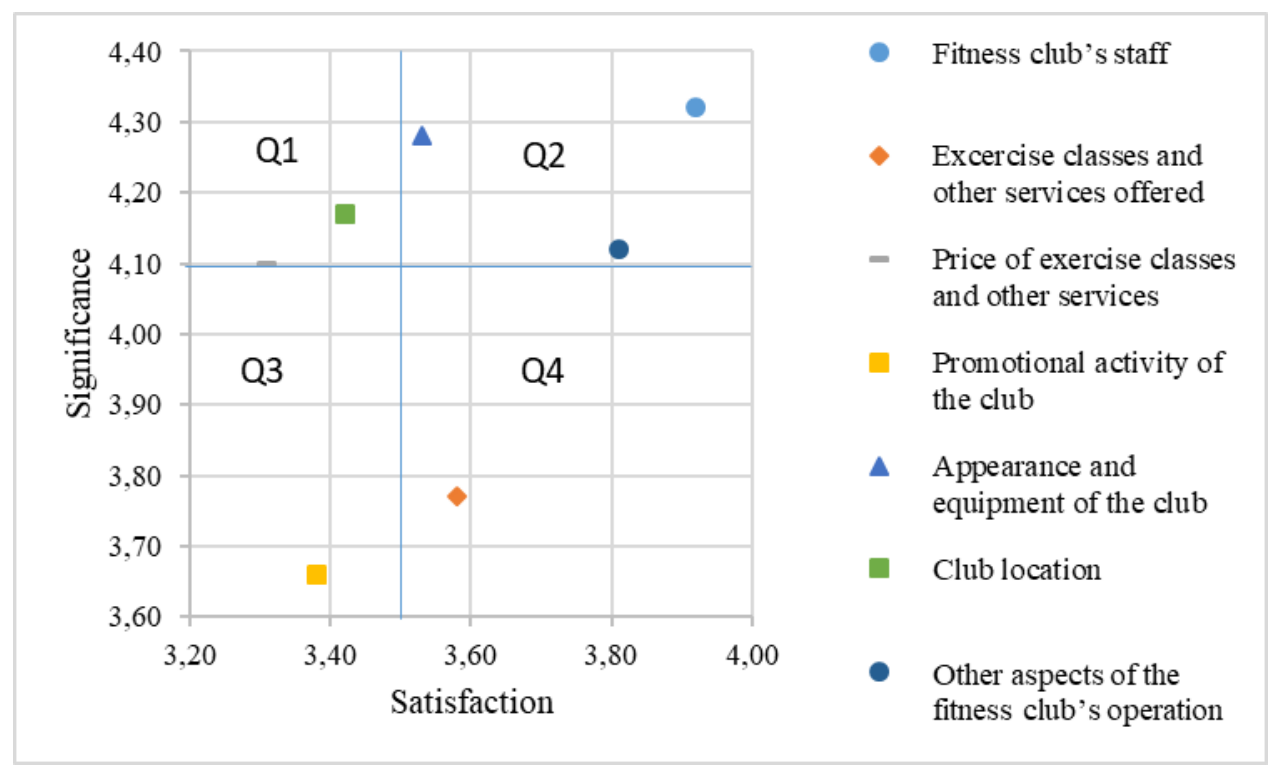

Graph 1. Customer satisfaction matrix of a fitness club

Source: own data.

Next, the extended version of the CSI was calculated (Kozielski et al., 2017, p. 70).

$$
\mathrm{CSI}=\frac{\text { sum of points awarded by customers in each category } x \text { appropriate weights }}{\text { number of categories }}
$$

The sum of points awarded by customers in each category and divided by the number of categories (in our case, score parameters) is the previously calculated arithmetic mean of each area on the satisfaction scale $\left(\bar{x}_{s}\right)$ (Table 4). However, there are no appropriate weights which, in the research available in literature on the subject, are determined by the given 
market experts, the organization's staff or by the customer group being studied (Śmiatacz, 2012). Due to the nature of the services and the specific fitness sector, the authors decided to use the significance scale to calculate the weights. This means that it was the respondents who indicated the level of significance for each parameter in the questionnaire. Based on the mean weights for the areas being studied, a standardised weight $\left(\mathrm{sw}_{\mathrm{i}}\right)$ was calculated for each area using the following formula: $s w_{i}=\frac{\bar{x}_{w}}{\sum w_{i}}$, where $\bar{x}_{w}$ is the mean weight for the area, and $\sum w_{i}$ is the sum of the mean weights.

Thus, the calculated CSI $\left(\mathrm{CSI}=\bar{x}_{S} \mathrm{x} \mathrm{swi}\right)$ is a derivative of the consumer's score on the satisfaction $\left(\bar{x}_{s}\right)$ and the significance scale $\left(\mathrm{sw}_{\mathrm{i}}\right)$ (Table 5). The highest CSI was recorded in the area associated with the fitness club's staff as well as the appearance and equipment of the club. The lowest scores were given by customers to the promotional activity of the club as well as exercise classes and other services offered. The data obtained make it also possible to calculate the $\%$ of the CSI based on the formula: \%CSI=(CSI/CSI max)*100\%. The \%CSI indicates the practical level of satisfaction. According to the criteria proposed by Wolniak and Skotnicka-Zasadzień (2008, p. 80), a \%CSI score of less than $76 \%$ means that respondents are not very satisfied with the product or service and higher percentage results suggest satisfaction.

Table 5. Basic measures of satisfaction of fitness club consumers in all areas studied

\begin{tabular}{lcclll}
\hline \multicolumn{1}{c}{ Area studied } & $\overline{\mathrm{x}}_{\mathrm{s}}$ & $\mathrm{sw}_{\mathrm{i}}$ & $\mathrm{CSI}$ & CSI $_{\max }$ & \%CSI \\
\hline Fitness club's staff & 4.32 & 0.15 & 0.65 & 0.75 & 86.4 \\
\hline Exercise classes and other services offered & 3.77 & 0.14 & 0.53 & 0.7 & 75.4 \\
\hline Price of exercise classes and other services & 4.1 & 0.14 & 0.57 & 0.7 & 82 \\
\hline Promotional activity of the club & 3.66 & 0.14 & 0.51 & 0.7 & 73.2 \\
\hline Appearance and equipment of the club & 4.28 & 0.15 & 0.64 & 0.75 & 85.6 \\
\hline Club location & 4.17 & 0.14 & 0.58 & 0.7 & 83.4 \\
\hline Other aspects of the fitness club's operation & 4.12 & 0.14 & 0.58 & 0.7 & 82.4 \\
\hline Sum & 29.42 & 1.00 & - & - & - \\
\hline
\end{tabular}

Note: $\overline{\mathrm{x}}_{\mathrm{s}}$ - mean score of satisfaction; $\mathrm{sw}_{\mathrm{i}}$ - calculated weight; $\mathrm{CSI}_{\max }$ - the maximum possible result in each instrument with regard to the assessed weight; \%CSI - satisfaction level.

Source: own compilation.

Only the weights for the 7 areas under analysis are shown in this document. This formula also makes it possible to calculate the weights for various score parameters in the relevant areas.

\section{Discussion}

The systematic measurement of the level of satisfaction of the organisation's customers makes it possible to improve the company's offer (Ferreira \& Fernandes, 2015) and to better tailor the product (service) to the target group (Lee et al., 2011). Some of the authors also believe that satisfaction is directly related to perceived service quality (Tsitskari et al., 2006), consumer loyalty (Mostert et al., 2016), and customer retention and company recommendation (Howat \& Crilley, 2007). The research of Kim and Lough (2007) shows that loyal consumers are more frequently satisfied with a company's offer. Other researchers have also demonstrated that a high level of satisfaction is related to the intention and actual repurchase of the product (Cronin et al. 2000).

As was indicated in the introduction, there are many ways of measuring consumer satisfaction. Apart from the CSI, researchers studying consumer satisfaction are able to 
choose from a number of other methods. However, the application of the other methods like the SERVQUAL model measuring customer satisfaction designed by Parasuraman, Zeithaml and Berry (1988) in the 1980s, seems to be quite complex, multi-stage and expensive. Other factors include that it is time-consuming and needs a thorough understanding of the context in which this model can be applied. Due to the weaknesses of this method listed above, small enterprises rarely apply it and, if they do, they outsource it to an external research company. Other methods are time-consuming and costly, like the Critical Incident Technique (CIT) developed by psychologist J.C. Flanagan. This is one of the direct methods considered to be one of the most accurate methods of measuring customer satisfaction with services (Bitner et al., 1990). Here, critical situations taking place while the service is being provided to the recipient are studied. Consumers are questioned through a survey about the most positive and most negative experiences associated with the studied company (Krzyżanowska \& Wajdner, 2000). The questions contained in the questionnaire are usually open-ended questions and the respondent is free to give their own answer. Since the nature of such a study is highly qualitative and the difficulties in standardising the research tool itself, the analysis of the data obtained requires increased effort on the organisation's part.

It is the classic survey-based study that is the satisfaction measuring method often used due to its simplicity and direct approach to the customer, its low cost, and the possibility of generalising and standardising the conclusions drawn from standardised surveys (Dziadkowiec, 2011). They are also frequently used as they allow small companies to conduct surveys on their own, without having to outsource them to external companies, doing away with complicated and expensive systems of customer relationship management. Usually, the outcome of such studies is quantitative data concerning consumers' opinions on specific elements of the organization's operations and its offer. The use of measuring tools in the form of satisfaction scales broken down according to selected areas of evaluation chosen by the company can prove to be very helpful in this situation. An interval 5-point Likert scale is often used, being a scale of aggregated numeral values assigned to the answers most frequently expressing a customer's acceptance or lack thereof. The advantage of using a welldesigned Likert scale is the ease with which the quantified data can be analysed and compared (Veal \& Darcy, 2014, pp. 320-321). Bigger scales, even 10-degree scales are also used, however. A dichotomous and contradictory scale is often applied to rule out the neutrality of the consumer's stance. So-called descriptive scales are also popular among companies, where sample sentences concerning the organisation are provided and consumers are asked to take a stance on them (Nieżurawski et al., 2010). These types of survey allow the overall satisfaction in relation to the entire company to be analysed, especially when the CSI (Customer Satisfaction Index) is used, which is one of the basic tools of measuring the effectiveness of marketing activities, making it possible to measure customer satisfaction with respect to previously specified categories considered as most important by the buyers (Nieżurawski et al., 2010).

In this article, the authors proposed an opinion poll survey using the CSI to analyse satisfaction in the selected fitness club company due to the simplicity and effectiveness of this method, which is particularly important in the case of small and medium enterprises. The areas with which customers are particularly dissatisfied were defined on the basis of the results of the survey and the use of the CSI. In this case, it made sense to intensify the research and use the focus group method and the user group method or direct personal interviews. The results of such supplementary studies provide qualitative data which will allow for a deeper analysis of the reasons for the dissatisfaction in selected study areas. Focus groups have made it possible to glean information difficult to detect in written interviews (Haffer, 2000). 


\section{Conclusion}

The measurement of customer satisfaction makes it possible for companies to take more informed decisions and contributes to the quality of services being rendered. This level of satisfaction can be seen as an opportunity for the fitness clubs being analysed. Please note, however, that customer satisfaction measured during our study does not necessarily guarantee customer satisfaction in the long run. Customer satisfaction is not constant and fluctuates as new experiences are gained. Therefore, it is necessary to continuously measure customer satisfaction and monitor how customers' needs and expectations change. It would also be worthwhile carrying out a larger study on a representative sample of fitness clubs and performing factor analysis of individual instruments.

Despite the existence of a number of methods measuring consumer satisfaction, there is no single, universal method of measurement of customer satisfaction that would do well in every sector and suit every consumer product and service. Corporations frequently use several methods to measure consumer satisfaction concomitantly, taking into account such factors as the degree of loyalty, the customer retention ratio, the company's turnover, and its market share (Nieżurawski et al., 2010).

Due to the two-dimensional structure of the CSI index (the scale of satisfaction and importance), we have a specific recommendation for fitness clubs, namely, that managers conducting satisfaction surveys should pay special attention to the instruments that the respondents identified as very important while assessing their overall satisfaction with the club's activity. This assessment was illustrated on the satisfaction matrix based on the SWOT theory. Our research has led us to recommend focusing more on areas that proved to be weaknesses and threats in terms of the fitness club's customer satisfaction level, namely, the fitness club location, price, and promotional activities.

The methodology of measuring customer satisfaction seems to be well adapted to the nature of customers of large fitness clubs and small and medium companies dominating this field. However, the customer satisfaction survey is subjective and must take into account other variables, for instance, the social background, habits, experiences, expectations, and needs of the customers. For this reason, the authors propose that more than one method of measuring customer satisfaction is used.

\section{Acknowledgement}

This paper was prepared within a framework of the DM 49 project of the Józef Piłsudski University of Physical Education in Warsaw on "Customer Satisfaction in fitness clubs as a factor of participation in sport and recreation". It was financed by the Ministry of Science and Higher Education in Poland.

\section{Ethical clearance}

The study design has been approved by the Senate Ethics Committee of the Józef Piłsudski University of Physical Education in Warsaw (No. SKE 08/2016).

\section{References}

Aldridge, A. (2006). Konsumpcja [Consumption]. Warszawa: Wydawnictwo Sic!

Alexandris, K., Palialia, E. (1999). Measuring customer satisfaction in fitness centres in Greece: An exploratory study. Managing Leisure, 4(4), 218-228. https://doi.org/10.1080/136067199375760 
Al-Nasser, A.D., Al-Rawwash, M.Y., Alakhras, A.S. (2011). An approach to setting up a national customer satisfaction index: The Jordan case study. Journal of Applied Statistics, 38(9), 1977-1993. https://doi.org/10.1080/02664763.2010.545107

Anitsal, I., Girard, T., Anitsal, M.M. (2012). An application of services marketing mix framework: How do retailers communicate information on their sales receipts? Business Studies Journal, 4(2), 77-90.

Baidya, M.K., Basu, P. (2009). Assessing Customer Satisfaction of 4Ps for a Brand in India. International Management Review, 5(1), 85-92.

Bartikowski, B., Llosa, S. (2004). Customer Satisfaction Measurement: Comparing Four Methods of Attribute Categorisations. Service Industries Journal, 24(4), 67-82. https://doi.org/10.1080/0264206042000275190

Baudrillard, J. (2006). Spoleczeństwo konsumpcyjne - jego mity i struktury [The consumer society. Myths snd structures]. Warszawa: Wydawnictwo Sic!

Bauman, Z. (2000). Globalizacja: I co z tego dla ludzi wynika [Globalization: the human consequences]. Warszawa: Państwowy Instytut Wydawniczy.

Berbeka, J., Niemczyk, A., Makówka, M. (2004). Badanie rynkowych zachowań konsumentów: Pomocnicze materiały dydaktyczne [Market study of consumer behavior: The auxiliary teaching materials]. Kraków: Wydaw. Akademii Ekonomicznej.

Bitner, M.J., Booms, B.H., Tetreault, M.S. (1990). The Service Encounter: Diagnosing Favorable and Unfavorable Incidents. Journal of Marketing, 54(1), 71-84. https://doi.org/10.2307/1252174

Bourdieu, P. (2005). Dystynkcja: Społeczna krytyka władzy sądzenia [Distinction: social critique of the judgement of taste]. Warszawa: Wydawnictwo Naukowe Scholar.

Cronin, J.J., Brady, M.K., Hult, G.T.M. (2000). Assessing the Effects of Quality, Value, and Customer Satisfaction on Consumer Behavioral Intentions in Service Environments. Journal of Retailing, 76(2), 193-2018.

Dziadkowiec, J. (2011). Badanie jakości usług świadczonych przez restauracje metodą ankietową i metodą mystery shopping [Using surveys and mystery shopping method to testing the quality of restaurant's services]. Zeszyty Naukowe Uniwersytetu Szczecińskiego: Problemy Zarzadzania, Finansów I Marketingu, 694(22), 33-44.

Elliott, K.M., Shin, D. (2002). Student Satisfaction: An alternative approach to assessing this important concept. Journal of Higher Education Policy and Management, 24(2), 197209. https://doi.org/10.1080/1360080022000013518

Ferreira, H.P., Fernandes, P.O. (2015). Identification of critical success factors that maximise customers' satisfaction: Multivariate analysis. Identificação De Fatores Críticos De Sucesso Que Maximizam a Satisfação Do Cliente: Uma Análise Multivariada, 11(1), $164-172$.

Fornell, C., Johnson, M.D., Anderson, E.W., Cha, J., Bryant, B.E. (1996). The American Customer Satisfaction Index: Nature, Purpose, and Findings. Journal of Marketing, 60, 7-18.

Giddens, A. (2002). Nowoczesność i tożsamość: "Ja" $i$ społeczeństwo $w$ epoce późnej nowoczesności. Biblioteka Socjologiczna [Modernity and self-identity self and society in the late modern age]. Warszawa: Wydawnictwo Naukowe PWN.

Gocłowska, S., Piątkowska, M. (2017). Service Satisfaction and Sport Consumption in The Fitness Center in Warsaw. European Journal of Service Management, 22, 31-37. https://doi.org/10.18276/ejsm.2017.22-04

Haffer, M. (2000). Satysfakcja konsumentów i jej pomiar [Consumer satisfaction and its measurement]. In S. Sudoł, J. Szymczak, M. Haffer, \& K. Andruszkiewicz (Eds.), Marketingowe testowanie produktów. Praca zbiorowa. Warszawa: Polskie Wydaw. Ekonomiczne. 
Howat, G., Crilley, G. (2007). Customer Service Quality, Satisfaction, and Operational Performance: A proposed model for Australian public aquatic centres. Annals of Leisure Research, 10(2), 168-195.

Hsu, S.-H., Chen, W.H., Hsueh, J.T. (2006). Application of customer satisfaction study to derive customer knowledge. Total Quality Management \& Business Excellence, 17(4), 439-454. https://doi.org/10.1080/14783360500528197

Johnston, R. (1995). The determinants of service quality: Satisfiers and dissatisfiers. International Journal of Service Industry Management, 6(5), 53-71. https://doi.org/10.1108/09564239510101536

Kim, H.D., Lough, N. (2007). Service Quality, Customer Satisfaction, and Repurchase Intention in Korean Golf Courses. Journal of Sport Management, 21(4), 606.

Kozielski, R., Pogorzelski, J., Dziekoński, M., Urbanek, G. (2017). Ocena marketingu na poziomie strategicznym [Marketing evaluation at strategic level]. In R. Kozielski (Ed.), Biblioteka Praktyków Zarządzania. Wskaźniki marketingowe (5th ed., 68-78). Warszawa: Wydawnictwo Nieoczywiste.

Krupa, P. (2017). Polish fitness market most dynamic in Europe. Retrieved from www.msp.gov.pl

Krzyżanowska, M., Wajdner, R. (2000). CIT - metoda badania jakości usług [CIT - a method for service quality research]. Problemy Jakości, 32(11), 9-12.

Lee, J.H., Kim, H.D., Ko, Y.J., Sagas, M. (2011). The influence of service quality on satisfaction and intention: A gender segmentation strategy. Sport Management Review, 14(1), 54-63. https://doi.org/10.1016/j.smr.2010.02.002

Lynch, J., Carver, R., Virgo, J. (1996). Quadrant analysis as a strategic planning technique in curriculum development and program marketing. Journal of Marketing for Higher Education, 7(2), 17-32.

Maison, D., Bruin, R. (1998). Usatysfakcjonować klienta [Satisfying a customer]. Marketing W Praktyce, 5.

Martilla, J., James, J. (1977). Importance - performance analysis. Journal of Marketing, 41, 77-79.

Mayntz, R., Holm, K., Hübner, P., Lipnik, W. (1985). Wprowadzenie do metod socjologii empirycznej [Introduction to the methods of empirical sociology]. Warszawa: Państ. Wydaw. Naukowe.

Meissner, Ł. (2013). Potencjał rozwoju klubów fitness w średnich i mniejszych miastach [Potential for the development of fitness clubs in medium and small cities]. Retrieved from www.bodylife.com.pl

Milner, R., Furnham, A. (2017). Measuring Customer Feedback, Response and Satisfaction. Psychology, 8(3), 350-362. https://doi.org/10.4236/psych.2017.83021

Mostert, P.G., Petzer, D.J., Weideman, A. (2016). The interrelationships between customer satisfaction, brand loyalty and relationship intentions of Generation Y consumers towards smart phone brands. South African Journal of Business Management, 47(3), $25-34$.

Nieżurawski, L., Pawłowska, B., Witkowska, J. (2010). Satysfakcja klienta: Strategia, pomiar, zarządzanie koncepcja wewnętrznego urynkowienia współczesnej organizacji [Customer satisfaction. Strategy - measurement - management. Concept of internal market orientation of modem organization]. Toruń: Wydawnictwo Naukowe Uniwersytetu Mikołaja Kopernika.

Parasuraman, A., Zeithaml, V.A., Berry, L.L. (1988). SERVQUAL: A Multiple-Item Scale for Measuring Consumer Perception of Service Quality. Journal of Retailing. (64), 1240. 
Public Relations Office Ministerstwa Skarbu Państwa. (2015). Polish fitness market most dynamic in Europe.

Rekha, R.S., Islam, M.A., Hossain, M.I. (2016). Measuring customer satisfaction using atm card in Bangladesh: an application of expectancy-disconfirmation theory. International Journal of Research in Commerce \& Management, 7(10), 24-30.

Ritzer, G. (2009). Magiczny świat konsumpcji [Enchanting a disenchanted world. Revolutionizing the means of consumption]. Spectrum. Warszawa: Warszawskie Wydawnictwo Literackie "Muza".

Rutgers, H., Hollasch, K., Struckmeier, J., Lehmkühler, B. (2015). European Health and Fitness Report 2015. UK, Europe Active.

Rutgers, H., Hollasch, K., Menzel, F., Lehmkühler, B. (2017). European Health and Fitness Report 2017. UK, Europe Active.

Rutgers, H., Hollasch, K., Struckmeier, J., Menzel, F., Lehmkühler, B. (2016). European Health and Fitness Market Report 2016. UK, Europe Active.

Seth, N., Deshmukh, S.G., Vrat, P. (2005). Service quality models: A review. International Journal of Quality \& Reliability Management, 22(9), 913-949. https://doi.org/10.1108/02656710510625211

Shin, D., Elliott, K.M. (2001). Measuring Customers' Overall Satisfaction: A Multi-Attributes Assessment. Services Marketing Quarterly, 22(1), 3-19.

Swan, J.E., Combs, L.J. (1976). Product Performance and Consumer Satisfaction: A New Concept. Journal of Marketing, 40(2), 25-33.

Śmiatacz, K. (2012). Badanie satysfakcji klientów na przykładzie rynku ustug telefonii komórkowej $w$ Polsce [Customers satisfaction survey on the example of the mobile services market in Poland]. Bydgoszcz: Wydawnictwa Uczelniane Uniwersytetu Technologiczno-Przyrodniczego; Uniwersytet Technologiczno-Przyrodniczy im. Jana i Jędrzeja Śniadeckich w Bydgoszczy.

Tsitskari, E., Tsiotras, D., Tsiotras, G. (2006). Measuring service quality in sport services. Total Quality Management \& Business Excellence, 17(5), 623-631. https://doi.org/10.1080/14783360600588190

Veal, A.J., Darcy, S. (2014). Research methods in sport studies and sport management: A practical guide. London: Routledge.

Wolniak, R., Skotnicka-Zasadzień, B. (2008). Wybrane metody badania satysfakcji klienta $i$ oceny dostawców $w$ organizacjach [Selected methods of customer satisfaction survey and supplier evaluation in organizations]. Gliwice: Wydawnictwo Politechniki Śląskiej; Politechnika Śląska.

Woodruff, R.B., Gardial, S.F. (1996). Know your customer: New approaches to understanding customer value and satisfaction. Malden: Blackwell.

Yu, C., Wu, L., Chiao, Y., Tai, H. (2007). Perceived quality, customer satisfaction, and customer loyalty: The case of lexus in Taiwan. Total Quality Management \& Business Excellence, 16(6), 707-719. https://doi.org/10.1080/14783360500077393 